\title{
Economic Diversification of Nigeria and Small and Medium Scale Enterprise (SME) Development (2000-2017)
}

\author{
Dr. Ikon, M.A* Ohue Paul Itua \\ Department of Business Administration, Faculty of Management Sciences, Nnamdi Azikiwe University, Awka, \\ Anambra State; Nigeria
}

\begin{abstract}
The broad objective of this paper is to assess the extent of relationship between economic diversification of Nigeria and SME development. Specifically, this paper seeks to ascertain the extent of relationship between new business development in Nigeria and technical skills acquisition by Nigerians. Expo-facto research design was adopted for the study, a panel data of 2000-2017 was used for the study, the augumented Dickey Fuller root test was used to test the stationarity of the data, while the analysis of the data was done using regression analysis. The findings revealed that there is a relationship between new business development in Nigeria and technical skills acquisition by Nigerians since $\left(\mathrm{R}^{2}=0.93, \mathrm{R}^{-2}=0.89, \mathrm{~F}=49.65\right)$. The researcher therefore concluded that economic diversification of Nigeria impacts SME development. It was against this backdrop that the researchers recommended that the Nigerian government should strive towards an improvement of the credit available to SME's and the Nigerian government should enactment and implement policies that would help curb the inflation rate in Nigeria as it affects the performance of SME's
\end{abstract}

Keywords: Economic Diversification, SME Development, New business Development, Technical Skill Acquisition.

DOI: $10.7176 / \mathrm{EJBM} / 11-14-03$

Publication date:May $31^{\text {st }} 2019$

\section{Introduction}

\subsection{Background of the Study}

Nigeria is one of the most populated countries in West Africa blessed with natural resources such as groundnut, cassava, coal, and crude oil. Despite these natural resources, Nigeria slipped into recession from the last quarter of 2015 to the first quarter of 2017 (National Bureau of Statistics, 2017). According to Onodugo, Amujiri, and Nwuba (2015) the Nigerian economy has for decades precariously leaned solely on crude oil. Consequently, it has had a chequered growth trajectory driven by the vicissitudes of oil prices. An emerging trend suggests that in the last seventeen years, the economy was growing without proper enactment and implementation of policies favourable to the development of Small and Medium Scale Enterprises (SME'S). It is a known fact across the globe that for a country to attain growth and development, its economy has to be diversified. Onodugo, Amujiri, and Nwuba (2015) described economic diversification as an act of investing in a variety of assets. The benefit of economic diversification entails reducing risk especially in the time of recession, inflation, deflation etc. One of the mechanisms that could foster the diversification of the Nigerian economy is the development of SMES. The development of small and medium scale enterprises (SME's) have been found all over the world to be capable of making positive impacts on the economy of a nation and the quality of life of the people (Storey, 2004). Small and medium enterprises play a key role in the development and diversification of the economy of developing countries (OECD, 2005). These firms typically account for more than $90 \%$ of all firms outside the white-collar jobs sector, constituting a major source of employment and generates significant domestic and export earnings. OECD, (2005) stressed that SME development plays a key role in the growth and development of any economy. World Bank review on small business activities establishes the commitment of the World Bank Group to the development of the SMEs sector as a core element in its strategy to foster economic growth, employment and poverty alleviation in developing countries in particular (Nigeria inclusive) (World Bank, 2012). Despite this effort, the development of Nigerian SME's is still retarded.

In the year 2005, the Nigerian government established the micro-finance policy. One of the key objectives of the policy is to "enhance service delivery (provision of financial support) by micro-finance institutions to small and medium scale enterprises" (Central Bank of Nigeria, 2005). It was intended that the micro-finance banks will "provide diversified, affordable and dependable financial services that would foster the growth of small and medium scale enterprises (Central Bank of Nigeria, 2005).

However, the establishment of these micro-finance banks by the Nigerian government has not impacted the Nigerian economy positively.

The foregoing gives credence to the determination of the effect of economic diversification on the development of Small and Medium Scale Enterprises in Nigeria. 


\subsection{Statement of the Problem}

Despite the numerous natural resources we are blessed with, Nigeria slipped into recession from the last quarter of 2015 to the first quarter of 2017 (National Bureau of Statistics, 2017). This is because Nigeria has failed to diversify its economy through the development of Small and Medium Scale Enterprises; thereby making Nigeria to solely depend on oil as its major source of revenue. The failure of Nigeria to diversify its economy by investing in SME's has negatively impacted the contribution of SME's to export.

The foregoing gives credence to the assessment of the effect the diversification of the Nigerian economy has on SME development.

\subsection{Objective of the Study}

The broad objective of the study is to assess the extent of relationship between economic diversification of Nigeria and SME development.

Specifically, this study seeks to ascertain the extent of relationship between new business development in Nigeria and technical skills acquisition by Nigerians.

\subsection{Research Question}

What is the extent of relationship between new business development in Nigeria and technical skills acquisition by Nigerians?

\subsection{Hypothesis}

Ho: There is no significant relationship between new business development in Nigeria and technical skills acquisition by Nigerians.

\subsection{Scope of the Study}

This study is focuses on economic diversification of Nigeria and SME development with a panel data of (20002017).

\section{Review of Related Literature}

\subsection{Conceptual Review}

\subsubsection{Economic Diversification}

Economic diversification is the process of allocating capital in a way that reduces the exposure to any one particular asset or commodity. A common path towards diversification is to reduce risk or volatility by investing in variety of assets or commodities (O'Sullivan \& Sheffrin, 2003). Recent research conducted by Varghese (2011) on SME's suggested that economic diversification primarily depend on the SME segment. The importance of economic diversification was further highlighted by Siddiqui and Al Athmay (2012) in their research on the Brunei economy, which is highly dependent on the oil industry. They observed that Brunei's current unemployment rate was $12 \%$ and that this was largely due to a lack of private sector investment in industries other than oil and gas. Sharma, Garg and Sharma (2011) opine that the development of SME's could aid the diversification strategy of any economy of the world.

\subsubsection{New Business Development}

New business development concerns all activities involved in realizing new business opportunities, including product or service design, business model design and market. It entails growing an enterprise with a number of techniques (Kotler, 2006). An idea central to new business development is that different product-markettechnology combinations can require different market strategies and business models to make them successful (Tidd, Bessant \& Pavitt, 2005). In other words, the new business development process is to recognize chances and opportunities in a fast changing technological environment.

\subsubsection{Small and Medium Scale Enterprises (SME's) Development}

The development of small and medium scale enterprises (SME's) have been found all over the world to be capable of making positive impacts on the economy of a nation and the quality of life of the people (Storey, 2004). Small and medium enterprises play a key role in the development and diversification of the economy of developing countries (OECD, 2005). These firms typically account for more than $90 \%$ of all firms outside the white-collar jobs sector, constituting a major source of employment and generates significant domestic and export earnings. OECD, (2005) stressed that SME development plays a key role in the growth and development of any economy.

Small and Medium Enterprises (SMEs) is a concept that tend to broadly explain the sizes of business in an economy. The meaning depends on purpose a definition is expected to support a particular policy governing the sector. However, there are three major factors used by countries in classification and definition of enterprises. These include; capital investment on plant and machinery, number of workers employed and volume of production (Aremu \& Adeyemi 2011, cited in Abubakar \& Yahya 2013). This concept of the small size firm is a relative one and it depends mainly on both geographical location and the nature of economy activities performed (Umar 1997). 
The concept was further expatiated by central Bank of Nigeria (CBN, 2010) as asset based and number of staff employed. The criteria include: an asset base between \#5 million and \#500 million and staff strength between 11 and 300. In the CBN report the small and medium Industries equity investment scheme (SMIEIS) in Nigeria saw SMEs as enterprises with a total capital employed not less than \#1.5 million but not exceeding \#200 million, including working capital but excluding cost of land and or staff strength of not less than 10 and not more than 300 as captured by (Abubakar \& Yahya, 2013). This idea concurred with the Central Bank of Nigeria's definition of SMEs.

\subsubsection{Technical Skill Acquisition}

Technical skill acquisition can be defined as the form of training by individuals or group of individuals that can lead to acquisition of knowledge for self sustenance. It involves the training of people in different fields of trade under a legal agreement between the trainers and the trainees for certain duration and under certain conditions. Ochiagha (1995) defined technical skill acquisition as the process of demonstrating the habit of active thinking or behaviour in a specific activity. He further stated that technical skill acquisition is seen as the ability to do or perform an activity that is related to some meaningful exercise, work or job. He maintains that for skill to be acquired, appropriate knowledge, attitudes, habits of thought and qualities of character are learnt to enable the acquirer develop intellectual, emotional and moral character which prepares him or her for a brighter future. Similarly, Donli (2004) is of the view that technical skill acquisition is the manifestation of idea and knowledge through training which is geared towards instilling in individuals, the spirit of new business development needed for meaningful diversification of the economy. He stressed that if individuals are given the opportunity to acquire relevant skills needed for self sustenance in the economy, it will promote their charisma in any work environment. He further maintains that skill acquisition increases competition and cooperation among people.

Accordingly, Magbagbeola (2004) posited that technical skill acquisition requires the accumulation of different skills that enhances task performance through the integration of both theoretical and practical forms of knowledge. He enumerated the guidelines for the sustenance of skill acquisition programme to include the followings;

-Provision of training that gives the trainees the opportunities to acquire skills that are appropriate for preparation in a field of trade for gainful employment.

-Provision of definite skills that relate to each trade that makes one a professional in one field instead of the others.

-Training have to be done by competent, experienced and qualified instructors

-Skill acquisition requires much practice, patience, interest, ability, aptitude and personality traits.

-Skill acquisition requires conducive environment.

- Training requires constructive human relationship, business skills, imitation and constructive ideas.

- The principles guiding training in a particular field in terms of attitude, customer-relationship, productivity, efficiency, supply and demand needs to be appreciated.

From the above scenario, it can be stated that skill acquisition helps in the transformation of knowledge and skills into creative venture.

\subsection{Theoretical Framework}

This study is anchored on Resource Based Theory propounded by Robert Grant in (1996). The resource-based theory comprises a rising and dominant area of the strategy literature which addresses the question of an organization's identity and it is principally concerned with the source, nature and utilization of strategic capabilities. The basis of the resource-based theory is that successful firms will find their future competitiveness on the development and utilization of distinctive and unique capabilities, which may often be implicit or intangible in nature (Teeche, Pinsno \& Shuen, 1991).

This theory is relevant to this study because the utilization of our strategic capabilities as a nation by investing in other productive areas like Small and Medium Scale Enterprises could impact the Nigerian economy positively.

\subsection{Empirical Review}

Raj and Shaukat, (2015) examined SME contributions for diversification and stability in emerging economies using SME's in Qatar as the case study. Questionnaire was used to collect data from seventy five (75) SME owners, simple percentage was used to analyse the collected data. The findings revealed that adequate financing and policies geared towards the development of SME's could impact the contribution of SME's to the economy.

Hassan and Shaukat, (2015) examined the effect of SME development on the growth and development of the Nigerian economy. The study revealed that adequate finance and favourable government policies could impact the contribution of SME's towards the growth and development of the Nigerian economy.

Akpomujere (2017) examined the challenges and improvement strategies in the diversification of the Nigerian economy through SME development. The population of study was 183 registered SME's in Warri, Delta state. Simple random sampling was used to select 91 SME owners. Questionnaire was the data collection tool employed, 
t-test statistics was used to analyse the collected data. The study revealed that various challenges affect the growth of Nigerian economy through SME development which include: low capital, poor access to loan, over taxation, Inadequate infrastructure and poor transportation.

Taiwo and Falohun (2016) examined the role of SME's on the development of the Nigerian economy. The study concluded that the Nigerian government should pay more attention to SME development as it could impact the Nigerian economy positively.

Oboh (2002) examined the effect of economic diversification on SME development in Nigeria. The study revealed that SME development has been retarded by a number of factors ranging from poor finance, poor economic conditions, unstable government policies, gross under capitalization, lack of infrastructural facilities, lack of transparency and corruption.

\subsubsection{Gap in Knowledge}

None of the empirically reviewed on diversification of the Nigerian economic and SME development employed the usage of secondary data as most studies resorted to the collection of data from SME owners. This is the gap in knowledge that this study intends to fill.

\section{Research Methodology}

\subsection{Research Design}

Expo-facto research design was used for the study. It was used because of the nature of the study.

\subsection{Method of Data Collection}

The data used for this study was collected from a secondary source. The study made use of annual time series data which was collected for a period of seventeen (17) years (2000-2017). The data was collected from the National Bureau of Statistics, 2017.

\subsection{Method of Data Analysis}

The researchers made use of ordinary least square (OLS) regression technique. This was aided by E views (version 10).

\subsection{Model Specification}

The model that was used for the empirical analysis of this study is specified below; Equation (1) is the function form of the model;

$\mathrm{TEX}=\mathrm{f}$ (CSME, GDP, INFL, MC, MCU ,NEX).

The theoretical model is as specified in equation (2).

TEX $=a_{0}+a_{1}$ CSME $+a_{2}$ GDP $+a_{3}$ INFL $+a_{4}$ MC $+a_{5} \mathrm{MCU}+a_{6}$ NEX $+U$.

a'priori expectation; $\mathrm{a}_{0}>0, \mathrm{a}_{1}>0, \mathrm{a}_{2}>0, \mathrm{a}_{3}>0 \mathrm{a}_{4}>0, \mathrm{a}_{5}>0$ and $\mathrm{a}_{6}>0$

Where: $\mathrm{TEX}=$ Total Export

CSME $=$ Credit to SME's

$\mathrm{GDP}=$ Gross Domestic Product

$\mathrm{INFL}=$ Inflation

$\mathrm{MC}=$ Money Supply

$\mathrm{MCU}=$ Manufacturing Capacity Utilization.

$\mathrm{NEX}=$ Non-oil export

$a_{0}, a_{1}, a_{2}, a_{3}, a_{4}, a_{5}$ and $a_{6}=$ Parameters to be estimated

$\mathrm{U}=$ Error term. 
Data Presentation and Analysis

4.1 Table 1: Unit Root Test

The Augumented Dickey Fuller unit root test was used to test the stationarity of the data.

\begin{tabular}{|c|c|c|c|c|}
\hline Variables & ADF at Level & $\begin{array}{l}\text { ADF at First } \\
\text { Difference }\end{array}$ & $\begin{array}{l}\text { Critical Value at } 0.05 \\
\text { Level }\end{array}$ & Remark \\
\hline LNTEX & $\begin{array}{l}-1.578813 \\
(0.4683)\end{array}$ & $-2.584371(0.0205)^{*}$ & -3.119910 & $\begin{array}{lll}\text { Stationary } & \text { at } & \text { First } \\
\text { Difference } & & \end{array}$ \\
\hline LNCSME & $\begin{array}{l}2.406294 \\
(0.9999)\end{array}$ & $-4.147319(0.0086)^{*}$ & -3.119910 & $\begin{array}{l}\text { Stationary at } \\
\text { Difference }\end{array}$ \\
\hline LNGDP & $\begin{array}{l}3.290219 \\
(1.0000)\end{array}$ & $-6.704702(0.0001)^{*}$ & -3.098896 & $\begin{array}{lll}\text { Stationary } & \text { at } & \text { First } \\
\text { Difference } & & \\
\end{array}$ \\
\hline LNINFL & $\begin{array}{l}-1.677103 \\
(0.4242)\end{array}$ & $-5.954499 *(0.0002)$ & -3.065585 & $\begin{array}{lll}\text { Stationary at } & \text { First } \\
\text { Difference } & & \\
\end{array}$ \\
\hline LNMC & $\begin{array}{l}3.137144 \\
(1.0000)\end{array}$ & $-7.845576(0.0000)^{*}$ & -3.098898 & $\begin{array}{lll}\begin{array}{l}\text { Stationary } \\
\text { Difference }\end{array} & \text { at } & \text { First } \\
\end{array}$ \\
\hline LNMCU & $\begin{array}{l}-4.482546 \\
(0.0631)\end{array}$ & $-3.153014(0.0426)^{*}$ & -3.065585 & $\begin{array}{l}\text { Stationary at } \\
\text { Difference }\end{array}$ \\
\hline LNEX & $\begin{array}{l}-1.185780 \\
(0.6550)\end{array}$ & $-3.522801(0.0214)^{*}$ & -3.065585 & $\begin{array}{l}\text { Stationary at } \\
\text { Difference }\end{array}$ \\
\hline
\end{tabular}

Source: Compiled from Eviews 10 Print-out

The result in table 1 shows that all the selected series are not stationary at level. This is evidenced by the fact that the ADF value for each of the series at level is greater than critical value (at 0.05 confidence level) in absolute terms. But when they were differentiated at first difference, they became stationary. This is because all the ADF values at first difference are greater than (0.05). The stationarity of the data shows that the data can be used for the analysis.

\subsection{Test of Hypothesis}

Ho: There is no significant relationship between new business development in Nigeria and technical skills acquisition by Nigerians.

Dependent Variable: TEX

Method: Least Squares

Date: 11/06/18 Time: 13:09

Sample: 20002017

Included observations: 17

\begin{tabular}{ccccc}
\hline \hline Variable & Coefficient & Std. Error & t-Statistic & Prob. \\
\hline \hline C & 5.214164 & 1.458027 & 3.707184 & 0.0005 \\
CSME & 0.543895 & 0.064456 & 0.818556 & 0.0393 \\
GDP & 0.182792 & 0.119053 & 3.535392 & 0.5425 \\
INFL & -.2 .549712 & 0.244531 & 0.891305 & 0.3449 \\
MC & 0.330195 & 0.560485 & 4.583731 & 0.4092 \\
MCU & 0.968513 & 0.411790 & 0.537898 & 0.4217 \\
NEX & 1.081905 & 0.551525 & 5.694250 & 0.3452 \\
\hline \hline & 0.933668 & Mean dependent var & 11.52104 \\
R-squared & 0.893869 & S.D. dependent var & 1.341205 \\
Adjusted R-squaredssss & 0.578741 & Akaike info criterion & 1.764728 \\
S.E. of regression & 11.54321 & Schwarz criterion & 2.099037 \\
Sum squared resid & -31.4519 & Hannan-Quinn criter. & 1.968139 \\
Log likelihood & 49.65946 & Durbin-Watson stat & 1.758495 \\
F-statistic & 0.000000 & & & \\
Prob(F-statistic) & & & & \\
\hline \hline
\end{tabular}

An explanation of the OLS result is presented below;

LNTEX $=f($ LNCSME, LNGDP, LNINFL, LNMC, LNMCU, LNEX)

LNTEX $=\mathrm{a}_{0}+\mathrm{a}_{1}$ LNEX $+\mathrm{a}_{2}$ LNCSME $+\mathrm{a}_{3}$ LNGDP $+\mathrm{a}_{4}$ LNINFL $+\mathrm{a}_{5}$ LNMC $+\mathrm{a}_{6} \mathrm{LNMCU}$

$\mathrm{LNTEX}=5.214164+0.543895 \mathrm{LNCSME}+0.182792$ LNGDP + -2.459712 LNINFL + 0.330195 LNMC + $0.968513 \mathrm{LNMCU}+1.081905 \mathrm{LNEX}+\mathrm{U}$ 
Critical F-statistics at $0.05=3.63$.

DW statistics $=1.758495$

The above result shows that the estimate of the constant is 5.214164. This implies that when all the explanatory variables are zero, total export earnings (LNTEX) will be approximately 5.214164. This value is consistent with a'priori expectation and it is statistically significant at 0.05 level. This significance is on the ground that the T-statistics (3.707184>2.120) at 0.05 level. The coefficient of SME credit (LNCSME) is 0.543895 . This indicates a direct relationship between (LNTEX) and (LNCSME). As such, a unit increase in SME credit will bring about a 0.543895 increase in total export earnings. This relationship is consistent with a'priori expectation and but it is not statistically significant at 0.05 level. This significance is on the ground that the T-statistics $(0.818556<2.120)$ at 0.05 level. The coefficient of GDP (LNGDP) is 0.182792 . This indicates a direct relationship between (LNTEX) and (LNGDP). As such, a unit increase in GDP will bring about a 0.182792 increase in total export earnings. This relationship is consistent with a'priori expectation and it is statistically significant at 0.05 level. This significance is on the ground that the T-statistics $(3.535392>2.120)$ at 0.05 level. The coefficient of inflation (LNINFL) is -2.549712. This indicates a negative relationship between (LNTEX) and (LNINFL). As such, a unit increase in inflation will negatively impact total export earnings. This relationship is consistent with a'priori expectation and it is not statistically significant at 0.05 level. This significance is on the ground that the Tstatistics $(0.891305<2.120)$ at 0.05 level. The coefficient of money supply $($ LNMC) is 0.330195 . This indicates a direct relationship between (LNTEX) and (LNMC). As such, a unit increase in money supply will bring about a 0.330195 increase in total export earnings. This relationship is consistent with a'priori expectation and it is statistically significant at 0.05 level. This significance is on the ground that the T-statistics $(4.583731>2.120)$ at 0.05 level. The coefficient of manufacturing capacity utilization (LNMCU) is 0.968513 . This indicates a direct relationship between (LNTEX) and (LNMCU). As such, a unit increase in manufacturing capacity utilization will bring about a 0.968513 increase in total export earnings. This relationship is consistent with a'priori expectation and it is not statistically significant at 0.05 level. This significance is on the ground that the T-statistics $(0.537898<2.120)$ at 0.05 level. The coefficient of non-oil export $($ LNEX) is 1.081905 . This indicates a direct relationship between (LNTEX) and (LNEX). As such, a unit increase in non-oil export will bring about a 1.081905 increase in total export earnings. This relationship is consistent with a'priori expectation and it is statistically significant at 0.05 level. This significance is on the ground that the T-statistics $(5.694250>2.120)$ at 0.05 level.

The F-statistics is 49.65946 while the critical F-statistics is 3.63 at 0.05 level. Since calculated F-statistics is greater than the critical-F, it shows that the F-statistics is significant.

The durbin Watson value is 1.758495 . By rule of thumb, there is absence of correlation.

\section{Discussion of Findings, Conclusion and Recommendations \\ 5.1 Discussion of Findings}

The findings reveals that there is a significant relationship between new business development in Nigeria and technical skills acquisition by Nigerians. This corroborates the work of Akpomujere (2017). He examined the challenges and improvement strategies in the diversification of the Nigerian economy through SME development. The study revealed that a diversification of the Nigerian economy could impact SME development. The work of Taiwo and Falohun (2016) on the role of SME's on the development of the Nigerian economy is also in line with the result obtained from the test of the hypothesis. The study concluded that the Nigerian government should pay more attention to SME development as it could impact the Nigerian economy positively. The work of Oboh (2002) on the effect of economic diversification on SME development in Nigeria also agrees with the result obtained from the test of the hypothesis. The study revealed that economic diversification could impact SME development.

\subsection{Conclusion}

The study concludes that economic diversification could impact SME development in Nigeria. The study shows that availability of SME credit, GDP, inflation rate, money supply and adequate compensation of employees of SME's could impact the non-oil export of Nigeria.

\subsection{Recommendations}

The researchers made the following recommendations based on the findings;

1. The Nigerian government should strive towards an improvement of the credit available to SME's.

2. The Nigerian government should enactment and implement policies that would help curb the inflation rate in Nigeria as it affects the performance of SME's. 


\section{References}

Abubakar, A.S \& Yahya, Z.A. (2013). Strengthening Small and Medium Enterprises (SMEs) as a Strategy for Poverty Reduction in North Western Nigeria. American Journal of Humanities and social sciences, vol.1, No.3, 189-201.

Akpomujere, O. (2017). Contemporary issues in Diversification of Nigerian Economy through Entrepreneurship. Journal of Technology, Management \& Business, 4 (2): 40-49.Central Bank of Nigeria. (2005). MicroFinance Policy, Regulatory and Supervisory Framework for Nigeria.Retrieved on the $3^{\text {rd }}$ of November 2018 from http://www.cenbank.org/out/Publications/guidelines/dfd/2006/microfinance\%20policy

Central Bank of Nigeria. (2010). Business expectations Survey. A Quarterly Publication of the Central Bank of Nigeria, $2^{\text {nd }}$ Quarter 2010.

Douli, J.G. (2002), An Overview of Nigeria's Economic reforms. Central Bank of Nigeria; Economic and Financial Review, 42(4).

Grant, R. M. (1996). Toward a Knowledge-based Theory of the Firm. Strategic Management Journal, 17, 109-122.

Hassan, D.N., Aku, S.U. \& Aboki, H. (2017). Small and Medium Scale Enterprises: A Tool for Economic Growth and Development in Nigeria. International Journal of Advanced Academic Research, 3(9).

Kotler, P. (2006). Principles of New Business Development. London: Wiley Press.

Magbagbeola, N.O. (2004). Theoretical and Conceptual issues in Economic Sector. Central Bank of Nigeria: Economic and Financial Review, 42(4).

Ochiagha, C.C. (1995). Theory and Practice of Career Development. Enugu: Snaap Press Limited.

Organization for Economic Co-operation and Development (2005). OECD SME and Entrepreneurship Outlook: 2005, OECD Paris, page 17.

Onodugo, I.C. Amujiri, B. A. \& Nwuba, N. (2015). Diversification of the Economy: A Panacea for Nigerian Economic Development. International Journal of Multidisciplinary Research and Development, 2(5), $477-$ 483.

O’Sullivan, A. \& Sheffrin, S.M. (2003). Economics: The Principles in Action. Upper Saddle River, New Jersey: Pearson Prentice Hall.

Raj, F. \& Shaukat, K. (2015). SME Contributions for Diversification and Stability in Emerging Economies: An Empirical Study of the SME Segment in Qatar Economy, pg 23-45.

Sharma, D., Garg, S.K. \& Sharma, C. (2011). Strategies for SMEs after Global Recession. Global Business and Management Research: An International Journal, 3,(1) 58-66.

Siddiqui, S. A., \& Al Athmay, A. R. (2012). Development and Growth through Economic Diversification: Are there Solutions for Continued Challenges Faced by Brunei Darussalam? Journal of Economics and Behavioral Studies, 4 (7), 397.

Storey, D. J. (2004). Entrepreneurship, Small and Medium sized Enterprises and Public Policies, In Z. J. Acs \& D. B. Audretsch (eds). Handbook of Entrepreneurship Research.Heidelberg, Gremany: Springer Science + Business Media.

Taiwo, J.N. \& Falohun, T.O. (2016). SME's Financing and its effect on Nigerian Economic Growth. European Journal of Business, Economics \& Accountancy, 4 (4): 37-49.

Teece D.J, Pisano G. \& Shuen A. (1991). Dynamic Capabilities and Strategic Management. Strategic Management Journal, 18(7): 509-533.

Tidd, J., Bessant, J. \& Pavitt, K. (2005). Managing Innovation: Integrating Technological, Market and Organizational Change, $3^{\text {rd }}$ Edition, Haddington: Scot Print.

Umar, A.B. (1997). Financing Small and Medium Scale Industries in Nigeria. A Paper Presented at a Day Conference Survival and Development of Small and Medium Scale Industry Sector in Nigeria, Nov.p13.

Update on Nigeria's Economic Situation. Retrieved from https://www. nbs.gov.sc on the $6^{\text {th }}$ of November 2018.

Varghese, T. (2011). The Small and Medium Enterprises in GCCs: A comparison between Sultanate of Oman and United Arab Emirates, The International Journal of Research in Commerce, Economics and Management, 1 (6), 1-4.

World Bank (2012). "A Diagnostic Review of the Small and Medium-Scale Enterprises Sector." Governance and Development, Washington: International Bank for Reconstruction and Development. World Development, 16(6), 667-681. 